\title{
THE EFFECTS OF MANDATORY LISTING ON THE MACEDONIAN STOCK EXCHANGE
}

\author{
Aleksandar Mateski ${ }^{1}$, Emilija Mateska ${ }^{2}$ \\ ${ }^{1}$ Department for Legal Affairs, Prilep' Brewery, University St Kliment Ohridski, Macedonia \\ ${ }^{2}$ Department at Faculty of Economy - Prilep, University St Kliment Ohridski, Macedonia
}

\begin{abstract}
:
One of the main features of the macedonian shareholding companies in the past was their lack of transparency, which went straight to the detriment of the minority shareholders and investors. Republic of Macedonia, in the interest of increasing transparency and thus reactivating of the stock market, providing more attractiveness to potential investors, but also to improve liquidity, on 15.03.2013 adopted new rules for listing by which is provided a new type of the listing on stock market. Since the adoption of new rules over 80 Macedonian companies found themselves on the market sub-segment - mandatory listing. Of those reasons mandatory listing was evaluated as a good example of positive change.

Nowadays when past more than a year of practical application of the new rules for listing, it seems quite logical and quite justified in this paper to make an analysis of whether the mandatory listing justify the initial goals and what effects has achieved.
\end{abstract}

\section{INTRODUCTION}

The weakening of stock exchange and also the constant shortcomings in terms of minority shareholders and visible transparency issues of the operation of shareholding companies were main motive for Macedonian stock exchange to establish new sub segment on the official share market - mandatory listing.

Legal presumptions for that modification were made by the Law on amendment of Law on securities published in (Official Gazette of RM 13/2013 dd. 23.01.2013) followed by new Rules for Macedonian stock exchange listing valid from 15.03.2013 as date for enforcement.

Special conditions that the publisher should fulfill for listing the shares on the sub segment "Mandatory listing" according to Article 6 of the rules are truthfulness and objectivity of financial reports, revised financial reports for last two years, nominal capital of at least 1.000 .000 euros, public distribution of type of shares of at least $1 \%$ and at least 50 shareholders. When calculating shares distribution, the shares of publisher's management body members are being exempted if they own 5\% of type of shares, shares owned by more significant shareholders with over $10 \%$ ownership of type of shares, as well as shares owned by Republic of Macedonia and state institutions if they own over 10\% of shares. In such way the criteria determined by Macedonian Stock Exchange JSC Skopje were set quite low in order to be met by as many shareholding companies so that they would appear on the market sub segment of mandatory listing. Mandatory listing measurement is valid until 30.04.2018. At this point after more than one year, it is the right time to analyze the effects of the mandatory listing.

\section{EFFECTS OF MANDATORY LISTING}

Establishing new rules resulted in new 84 companies on the stock exchange sub segment - Mandatory listing. From 90 reviewed requests, 86 were accepted for listing on the sub segment Mandatory listing for which decisions for accepting of listing requests were made, and two of the shareholding companies did not submit listing contracts. Most of them, according to reference [4] belong to the industry sector - 40 are shareholding companies, followed by 19 services companies and 13 trade companies. Even 40 of the shareholding companies have been established in Skopje, which is a real display of the territorially centralized condition of Macedonian economy. In that way the dominant stock exchange part, with total of 116 listed shareholding companies, belongs to shareholding companies of the sub segment Mandatory listing, above shareholding companies of sub segments Super listing and Stock exchange listing.

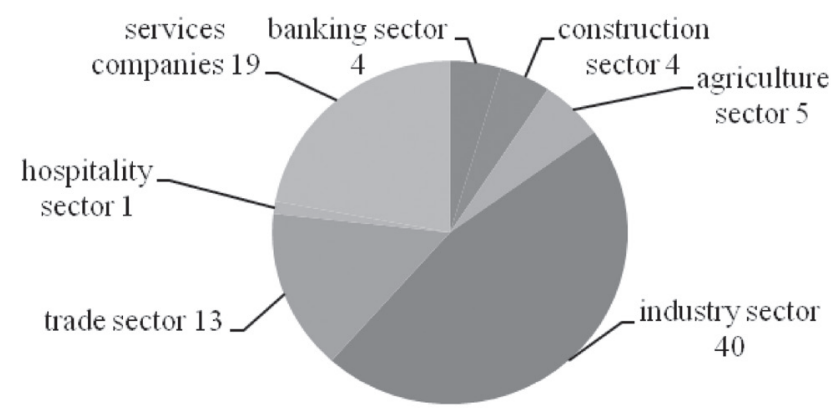

Image 1. Graphic display of shareholding companies with decisions to be accepted in the market sub segment "mandatory listing" according to their business activity.

Listing includes sequence of specific obligations related to informing the publishers for complete consolidated and unconsolidated financial reports, audit opinion, balance sheet, income balance, cash flow reports, capital changes report and notification for financial reports within 7 days of adoption on Shareholders Assembly, decisions made on Shareholders Assembly for adoption of financial reports, distribution of income, dividend distribution and determination of dividend calendar, change of rights of issued securities, change of members of management body and status changes. Referance [4] shows that in 2013 listed companies published 469 information related to shareholders assembly and decisions of companies' manage- 
ment bodies and 413 other price sensitive information. All companies published unrevised income balances and balance sheets on 390 separate publications on SEI-NET, of which only 12 shareholding companies delayed the publication of half-year notifications and did it outside the deadline, owing to the novelty of obligation and companies organizational issues.

Investors would like to invest in a well known company, and a necessary condition is having parameters based on which they will be able to sufficiently research and analyze it before making any investment decision. On the one hand reserved and negative attitude of companies in terms of their obligations for transparent operation and publication of additional information in most cases is due to fear of possible disorder in the equity of company management. Reserved attitude was also a bit due to the additional cost related to the stock exchange listing, which in the end is not such a big burden on the companies. Reference [5] shows that cost mostly refers to preparation of prospect of companies as a onetime cost directly agreed with the patrons (there are about ten patrons - brokerage firms/banks, stock exchange members and they act as mediators between the stock exchange and publishers in the process of listing of securities and help the publisher in fulfilling his /her obligations on the basis of listing) onetime fee for shares listing of 10.000 denars (around 163 euros) and annual fee for shares listing of 75.000 denars (around 1218 euros). Such amounts charged by the stock exchange are one of the lowest in the wider region and for that reason they should not be taken as serious excuse for the resistance by part of the companies. On the other hand Reference [4] shows that such income prevented the stock exchange to display loss before taxation for more than 6 million denars for 2013 (total income based on listing fee of newly listed companies - onetime and annual fee, were in the amount of 7.135.000 denars).

One of the more active companies on the market sub segment mandatory listing is "Makedonski Telekom" (with market capitalization on 31.12.2013 of 37.391.500.000 denars), „Cementarnica Usje“" (7.329.192.000 denars), "Stopanska banka Skopje“ (3.003.151.000 denars), "NLB Tutunska banka" (1.964.340.000 denars), „Uni banka“ (424.356.000 denars), „Agroplod“ (250.198.000 denars), „Prilepska Pivarnica“ (382.414.000 denars), „Pelisterka“ (103.873.000 denars), „Octa“(406.253.000 denars), „Evropa“ (803.809.000 denars), „Mermeren kombinat Prilep“ (2.577.772.000 denars), „ArcherolMittal CRM“ (850.088.000 denars). Market capitalization of listed stocks on 31.12.2013 reached 97.76 billion denars i.e. about 1,6 billion euros. The increase of $277 \%$ is precisely due to new companies listed on the sub segment Mandatory listing.

This change provided the necessary centralized collection, processing and using of information for listed companies which greatly increased the efficiency of Macedonian securities market.

Companies which appear on market sub segment mandatory listing publish notifications on a separate web based application - Electronic notification system SEI-Net. For any previous modification i.e. entering a notification according to the rules for listing, companies whose shares are listed on the mandatory listing have to authorize individuals for publishing the notifications who have access by entering user name and password. Publications are inspected and approved by the Stock exchange before every notification, and controllers, people who represent the companies for better informing and control over published data, are also informed regarding the publication. Before start of functioning of the system, Macedonian Stock Exchange held five practical trainings and introductions of companies involved to the way of system functioning which provided the necessary part of regular implementation of legal provisions.

Not only the new market sub segment, but also the changes of Law on Companies which were complementary to the chang- es of Listing Rules helped increase the transparency of operation of companies. These changes largely closed the problem with companies' operation transparency. There are no more situations when only shareholders were entitled to materials insight and only personal materials insight could be done, the hostile atmosphere towards minority shareholders, big obstacles for future investors to have insight in companies operation.

Stock exchange listing also includes obligations of companies according to the Law on Companies in terms of information which must be published on the company's web site before holding a Meeting of Shareholders Assembly. Publication refers to the call, information for total number of stocks and voting rights of stocks, suggested decisions, voting forms as well as documents and materials subject to reviewing on the meeting of companies' shareholders assembly. Companies' operation transparency has widely improved by the right of every shareholder to ask questions about each agenda item on the meeting of company's assembly and the obligation of the company to publish questions and answers on its web site in question answer form.

But companies' operation transparency is not conditioned only by respecting their obligations for materials publication, but also by the extent of content corresponding to the legal obligations. Here, the main issue refers to the weak data of annual reports for companies operation prepared by the management and the supervisory board of companies. Namely, despite clear provision of Article 384 paragraph 7 of Law on Companies, only small number of companies' publish all information for which publication there is a legal obligation. So, there are often reports for company operation prepared on only 3-4 pages, which is certainly not sufficient for introducing the shareholders to and objective presentation of main factors and circumstances which influenced the company operation, company development plans and on all other clearly stated items. Hence, in future it would be necessary to define the responsibilty of companies also in cases when the content of information which companies are obliged to publish does not correspond to the legal obligations. The formal side of mandatory listing has proven as the right step for increasing the transparency of companies, but still an implementation of liability is necessary including for violations when information, especially in annual reports for companies operation do not correspond to legally defined content. So, quite illustrative is the example of not publishing the income of members of management and supervisory board in the companies with two-stage management system, i.e. members of board of directors of one-stage system. Of all companies' operation reports, last year, only in two companies published data for income of members of management and supervisory boards, as long as all other companies remained silent on the obligation for publication of annual income or did not publish them at all or did it collectively which is of course contrary to the obligation of the Law on Companies. Shareholders have a right to all information clearly stated in the Law on Companies and in any case avoiding of fulfilling the legal obligations should be done under excuse of confidentiality.

\section{CONSLUSION}

Modification and implementation of market sub segment mandatory listing on Macedonian Stock Exchange have greatly improved the companies' operation transparency which is of benefit not only to the shareholders, but also to all potential investors and the economy in general. A next step for further improvement of companies' transparency is considering implementing liability for insufficiently clear, i.e. incomplete annual reports for companies' operation. 


\section{REFERENCES}

[1] Рукер Рудикер, Тргување со хартии од вредност, прирачник за самостојно учење, Скопје, Македонска берза 2012.

[2] Водич за задолжителна котација, Скопје, Комисија за хартии од вредност, 2013.

[3] Правила за котација, Македонска берза на хартии од вредност АД Скопје, 15.03.2013.
[4] Извештај за работа на Македонска берзаАД Скопје за 2013 година, Скопје, февруари 2014.

[5] Тарифник за висината на надоместоците на Македонска берза А.Д. Скопје, 27.05.2013.

[6] Правила за тргување, Македонска берза на хартии од вредност А.Д. Скопје, пречистен текст, Скопје, декември 2013 година.

[7] Закон за хартии од вредност, Службен весник на Р. Македонија бр.95/2005, 25/2007, 7/2008, 57/2010, 135/2011, $13 / 2013,188 / 2013,43 / 2014$.

\section{ЕФЕКТИТЕ ОД ЗАДОЛЖИТЕЛНАТА КОТАЦИЈА НА МАКЕДОНСКАТА БЕРЗА}

Александар Матески ${ }^{1}$, Емилија Матеска²

${ }^{1}$ Прилепска Пиварница АД, Прилеп, Р. Македонија, mateski@pripiv.com.mk

${ }^{2}$ Економски факултет-Прилеп, Универзитет Св.Климент Охридски-Битола, Р. Македонија, emilija.mateska@yahoo.com

\section{Апстракт:}

Една од основните карактеристики на македонските акционерски друштва во минатото беше нивната нетранспарентност, што одеше директно на штета на малите акционери и на инвеститорите. Република Македонија, во интерес на зголемување на транспарентноста, а преку тоа и раздвижување на пазарот на хартии од вредност, обезбедување на поголема атрактивност за потенцијалните инвеститори, но и подобрување на ликвидноста, на 15.03.2013 година донесе нови Правила за котација со кои е предвиден нов вид на котација на берзата. Од донесувањето на новите правила преку 80 македонски компании се најдоа на пазарниот подсегмент- задолжителна котација. Задолжителната котација од тие причини беше оценета како добар пример за позитивна промена.

Денес кога е измината повеќе од една година од практичната примена на новите правила за котација, се чини сосема логично и сосема оправдано во овој труд да се направи анализа на тоа дали задолжителната котиција ги оправда почетните цели и кои ефекти ги постигна.

\section{Клучни зборови:}

акции,

котација,

транспарентност,

извештаи,

македонска берза. 